\title{
A KINGDOM WITH MANY INTERNAL FACETS: POWER, POLITICS AND INSTABILITY IN A POST-COLONIAL STATE. RAMIFICATIONS FOR PUBLIC STABILITY
}

\author{
Daniel N. Mlambo \\ Department of Public Management \\ Tshwane University of Technology \\ 2 Aubrey Matlakala str., Soshanguve, South Africa, 0152 \\ mlambodn@tut.ac.za
}

\begin{abstract}
Lesotho offers an exciting case study for the analysis of the interface between power, politics and instability. Since gaining its independence from Britain in 1966, Lesotho has over the last five decades been plagued by persistent political instability that has paved way for the breakdown of the rule of law, gross human rights violations, underdevelopment and insecurity where at times the security sector like the Lesotho Defence Force has taken over several key institutions in the country. Political instability in the tiny kingdom has been a daunting agenda for all concerned actors, including political parties, civil society, the Southern African Development Community (SADC) and other continental stakeholders. While the security sector of any state is of importance, it becomes problematic if it becomes involved in a state's political affairs. The repercussions of such trajectories of governance have been quite profound for democratic stability and security. Using a qualitative methodology, supplemented by secondary data, this article seeks to unearth Lesotho's political instability, the role of its security forces and continental actors in its continuous internal governance crisis post the colonial era. The article rightfully shows that The power, possessed by both the military and police, has made them have a robust role in state affairs rather than institutions, mandated to safeguard Lesotho's citizens. The legitimacy of the security sector underpins restructuring, transparent and accessible security sectors enhance healthy civil-military relations. Restructuring a state's security and political dynamic reforms is not an easy task, it requires a state managerial and dedication prowess and assistance from different role players and therefore an ample amount of time and effort is invested in the coordination of this process
\end{abstract}

Keywords: Lesotho, Security Forces. Political Instability, Military Coup, SADC.

DOI: $10.21303 / 2504-5571.2021 .002161$

\section{Introduction}

Africa's post-colonial challenges, widespread violence, territorial disputes, ethnic and political conflict and instability have become to represent the highest challenge to peace and stability. The tiny kingdom of Lesotho (Fig. 1) celebrated its $55^{\text {th }}$ independence anniversary on the $4^{\text {th }}$ of October 2021. Lesotho, a tiny kingdom with a population of about 2.1 million and wholly surrounded by South Africa, gained its independence from Britain in 1966.

It is, therefore, somewhat, fitting that as Lesotho looks back at some of its milestones, we also reflect on the manifestations of its continuous instability post its colonial era. The Lesotho democracy and security political landscape has been shaped and influenced largely by both regional and continental post-colonial dynamics. As Motsamai [1] aptly observes that while democracy had rejuvenated interest in the functional institution's accountability, some Southern African states have struggled to develop effective states that reconcile economic growth with equitable objectives. The demise of the Cold War witnessed a marked change in both the foreign and defence policies of most countries globally. Although there was no longer a perceived external threat, states started to look inward when assessing the real threat to their security [2]. Lesotho is now a fully sovereign state and a member of the United Nations (UN), the Commonwealth of Nations and the Southern African Development Community (SADC).

Over the years, the country has witnessed and battled immense internal security issues that have led to the execution of high-ranking individuals. Barely two decades since attaining independence, a coup by the Royal Lesotho Defence Force in 1986 led to general Justin Lekhanya becoming head of state until 1993. A short-lived democracy was restored in the 1993 elections after the victory of the Basotho Congress Party (BCP). In 1997, the BCP split and a majority of its members 
of parliament joined the Lesotho Congress for Democracy (LCD), which came into power. A year later, (1998) an army coup was subdued by intervention from the SADC and an interim political authority was established and facilitated new elections in 2002 [3]. From assassination attempts to coups, Lesotho has been a very unstable country in the Southern African region irrespective of its relatively small population.

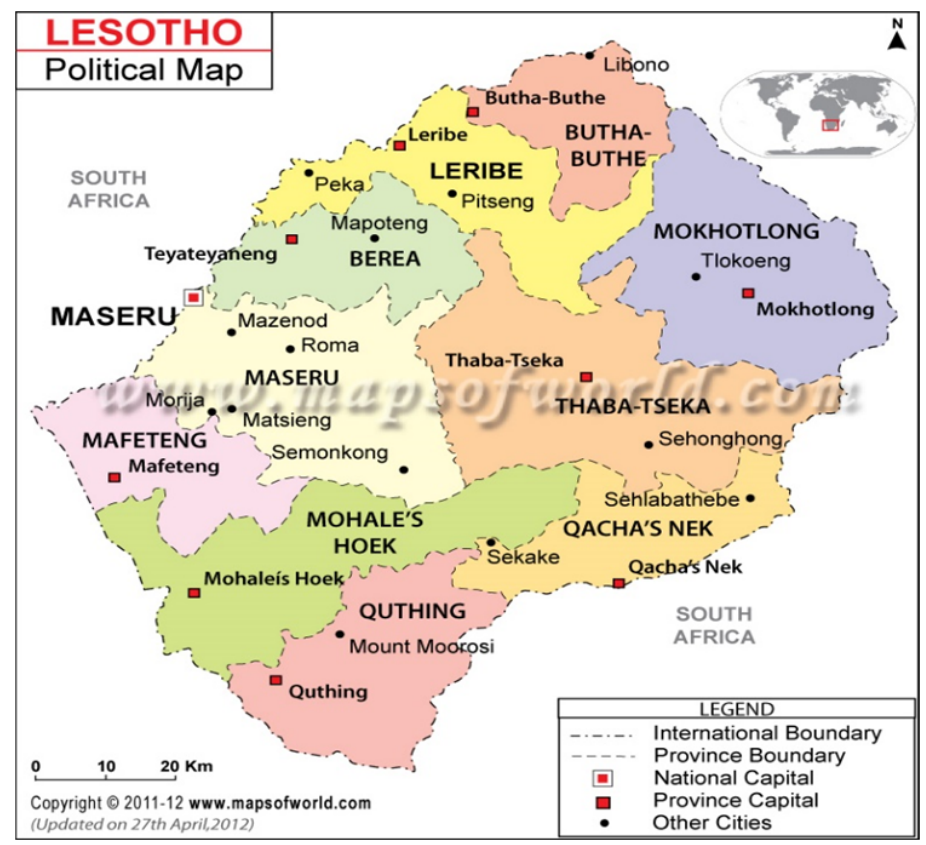

Fig. 1. Map of Lesotho. Source: Maps of the Word (2021)

For more than five decades, internal political instability, weak democratic institutions and security challenges have characterized Maseru (the capital city of Lesotho). Malephane [4] is of the view that theorists of Nationalism in their view of providing insights into the motives of political instability in states are of the notion that there are two types of interacting participants, those who defend a given order and those who challenge it or are seen as challenging it. From the Basotho perspective, while there are those (political actors and military elites) who defend a given order, in most cases some want to challenge it, as it does not suit their interests or those of their allies. Similarly, the author argues that the challenges in Lesotho are that conflict in numerous cases comes from within government and security forces rather than nationalist movements, in what Malephane [4] calls a contest between those who run the state and those who challenge it. In the past decade alone, high-ranking officials of the LDF have been assassinated and many political figures in Lesotho have had to flee to South Africa for safety reasons. Drawing from the preceding, over the years, various continental actors have partaken to restore order in the Kingdom. Lesotho is a parliamentary constitutional monarchy with King Letsie III as head of state and executive powers reside with the Prime Minister. In its constitution, policy and legal frameworks, Lesotho establishes four primary institutions responsible for security.

These are made up of (1) the Lesotho Defence Force (2) Lesotho National Security Services (3) Lesotho Mounted Police Services and (4) Lesotho Correctional Services [5]. Using a qualitative methodology, supplemented by secondary data, this article seeks to unearth Lesotho's political instability, the role of its security forces and continental actors in its continuous internal governance crisis post the colonial era. It further aims to highlight the territorial politics in Lesotho and the role its internal intelligence services and external actors have played in trying to deal with the situation post its independence era. The article grapples with the continuous entrenched culture of violence in contemporary Lesotho. However, the aim is not to draw an ample historical over- 
view of such events, but rather, to draw on specific events that have contributed to the continuous political mayhem.

\section{Material and Methods}

Brynard, Hanekom and Brynard [6] opine that the research methodology pertains to the planning, organization and execution of research to obey the demands of truth, objectivity and validity. Having a research methodology is important in research as it offers the reader an understanding of how data was retrieved [7]. In knowledge production, there are some essential theoretical and rational anticipations that institute well-organized research in a specific study. From a scholarly perspective, research methodology has to do with how data is gathered and processed, however, no methodology is considered sacrosanct predominantly in the social science domain.

There are three main methods one can employ when undertaking research, these consists of qualitative, quantitative or a mixture of the two, commonly known as the mix method. This article adopted a qualitative research methodology, supplemented by secondary data. When one adopts this kind of method, s/he expects to gather a strong perspective, relating to human behaviour and the justification behind it. All data was sourced from secondary sources, including books, chapters in books, journal articles, trustworthy online sources, government documents and policy briefs that monitor Lesotho's post-independence political landscape. This presented the researcher to have a robust and wider explanation on the topic under investigation. The data was further subjected to comprehensive qualitative analysis using content analysis. Content analysis is a systematic approach to qualitative data analysis that identifies and summarizes message content and makes use of accurate reflection and analysis of primary and secondary data collection [8]. This method assisted in analyzing and reacting to articles from diverse sources.

\section{Results}

3. 1. The Security Services' and Lesotho's Instability: Historical and Current Context(s)

The Lesotho conflict can only be understood with a concise exposition of the country's historical context. However, the intention is not to draw a complete historical overview of the history of Lesotho, but, the researcher has carefully narrated the events relevant to this article. Before colonization, Lesotho had an absolute monarch. The British ruled the Basotho through the monarchs of Letsie I (1870-1891) and Lerotholi (1891-1903). The Kingdom is based on the pre-colonial state of Basutoland, which was established by Moshoeshoe in 1822. Benyera [9] maintains that after the Lifaqane wars of 1815-1840, king Moshoeshoe amalgamated the many fragmented Sesotho speaking people to form a nation, living on the mountains of modern-day Lesotho. Moshoeshoe forged a new nation from minor groups and refugees from the lifaqane period in Southern Africa.

The monarchy continued being functional from 1822 to the present day, however, lost executive power at the time of independence. As Sefa - Nyarko [10] puts it, just like most African countries, Lesotho has struggled to maintain social cohesion and political stability and this has also been driven by the tripartite challenge of socio-cultural frictions, democratic institutionalism and law legitimacy. A plethora of reports on Lesotho, ranging from academic to print media, all replicate a state that lies at the heart of robust political instability and citizens that live with uncertainties and insecurity mainly due to political instability [11-14]. Molomo [15] posits that this stems from a culmination of deep tensions since independence, driven by political greed and security services, possessing a say in the administration of the state. Various scholars [15-18] have pointed that the instability in the Kingdom originates from the security sector's involvement in state politics, repeatedly pointing to the military and its refusal to at times cooperate with the government.

Since the 1990s, the military has in many instances violated the rule of law, abused basic human rights and retarded the process of democratization. Over the last few decades, African heads of state have not shown robust enthusiasm for developing expertise in security matters. Security services may be conceptualized as government-sponsored agencies, dedicated to gathering information to retain state or national goals and uphold national security. Pateman [19] claims that becoming involved in establishing and preserving effective security networks brings with it a need to establish a country's foreign policy. From a global perspective, security services may have 
overlapping intelligence capabilities in many countries and defining the role of different services and ensuring that all intelligence provision is under democratic control is a common challenge [8].

Schreier [20] emphasizes that the need for security services has become an inevitable necessity for any modern government, as only a handful of countries globally believe they can do without them. Caparini [21] puts forth the argument that security services are crucial mechanisms of any state, providing analysis and information appropriate to the internal and external security of the state and security for the protection of vital national interests. As with any country globally, citizens of democratic states should expect effectiveness, competence, sound management and value for money for their security services.

Nevertheless, if not subject to control and oversight, the security sector's unique characteristics and proficiency in surveillance to carry out operations may serve to undermine democratic governance and the fundamental rights of citizens. Robust intelligence arises in terms of establishing effective oversight mechanisms for this sector, and democratic states need to ensure that security does not influence nor hinder party politics. Security services, inherited from authoritarian or totalitarian regimes, may pose dire threats to the development of new democracies. Hence, security services in oppressive governments are often a key means of maintaining power and are often utilized to identify domestic political opponents and neutralize opposition to the government [7].

When the security sector supports a repressive regime via what Caparini [21] call political policing, these services are regularly complicated in human rights abuses, persuasive surveillance, harassment of citizens, torture and political detention among others. From an Afrocentric perspective, being in a state's security service often brings with it danger particularly if one holds a high position. This has been partially driven by the fact that contestation for political power has perceived many individuals in high positions as a tool to be employed against their rivals [22]. In recent decades and in Lesotho in particular, powerful individuals have been overthrown, exiled or executed. Literature $[23,24]$ in security services is replete with studies of intelligence in established democracies, such as the United States of America and the United Kingdom.

However, there seems to be a skim amount of literature on how African post-colonial states engage in reforms of their security services. This stems from many reasons with one being this is still a relatively new path for most African democracies, some of which are still witnessing authoritarian regimes. Hutton [25] further narrates that in Africa, the formation of security services may be traced to the colonial period and was mainly established to protect colonial interests as some political elites used these services to gain and retain political power.

Lijembe [26] groups security services in all types of political regimes, authoritarian and democratic into three distinctive categories (1) the Bureau of Domestic Intelligence (2) Political Police and (3) Independent Security state. The Bureau of Domestic intelligence possesses restricted and precise powers, derived from a legal character or statute, and its core function is to gather information, relating to criminal prosecution of security offenders. The political police operatives possess greater autonomy from democratic policy-making and are generally more insulted by the legislature and judicial security. This type of intelligence often responds almost completely to the political elites or party in power and focuses on internal political opposition groups and steering hostile contradicting operations against domestic political opposition to the existing regime. The Independent security state is often characterized by a lack of external control and oversight even from the authoritarian government it is allegedly protecting.

It often keeps the funding and policies hidden from government policy-making. As alluded to earlier, the constitutional, policy and legal frameworks of Lesotho establish four primary state institutions responsible for security, these include (1) the Lesotho Defence Force (2) Lesotho National Security Services (3) Lesotho Mounted Police Services and (4) Lesotho Correctional Services. The LDF is established by Article 146 of the 1993 constitution that outlines that "there shall be a Defence force for the maintenance of internal security and the security of Lesotho". The commander in chief acts as the Prime Minister and he/she determines the operational use of the LDF. However, the appointment of the commander rests with the King. For Matlosa [27], major policy initiatives have been undertaken since 1994 to refine the LDF with the notion of entrenching civil authority over the armed forces. First on the agenda was the establishment of the Ministry of 
Defence (MoD) in 1994. The MoD aimed at developing a defence policy, envisioned to transform the LDF into a political, accountable, capable and affordable defence force. Secondly, another critical element of the security reform process in the LDF was geared toward the adoption of a defence policy from 1995 [28].

This was intended at developing a vision for the LDF and corroborating the mission of the $\mathrm{MoD}$, concerning fostering and consolidating the ongoing process of the security sector reform. In 1996, the Defence force policy was passed geared at providing the structure organization and administration together with disciplines for the forces. Matlosa [29] points out that the army, evolved as parliamentary police, the police mobile unit, in the 1960s transformed into a modern army in the 1980s and the LDF in 1986. The Basotho National Party (BNP), which emerged to political power because of the support of the security forces, was dislodged by a military coup. In turn, military-ruled Lesotho from 1986-1992. A critical avenue of the democratic government that came into power in 1993 was to create a civilian authority to manage the affairs of the military and also ensure that it was accountable to the state. While the researcher argues that (as in most democratic states) this has been the case, post the 1993 era, the security architecture of Lesotho has been in most cases thrown in turmoil due to the persistent instability, which at times is brought by the military.

The Lesotho National Security Services (NSS) is an intelligence service that provides information on possible threats in support of internal and external security, and the Prime Minister has direct authority over the NSS [30]. The NSS is established under article 148 of the national constitution and charged with the protection of national security. In 1872, the Batsotholand Mounted Police was formed. Just like the LDF, the LMPS has been an extremely politicized force and at times primarily utilized as an instrument of intimidation to control or eliminate its political opponents. Post-1993, three vital initiatives to reform the LMPS have been introduced. These have included the 1997 White Paper in Police reform, the 1998 Police service act together with a 5-year Development plan (1998-2003). The core aim of these was to stimulate a professional service, envisioned to discharge its law and other functions with no political bias. Both the LMPS and LDF are responsible for maintaining internal law and order and any external threat that may arise.

The Lesotho Correctional Services is located in the Ministry of Justice, Human rights and Correctional Services. The core aim of the Ministry is with the dispensation and administration of justice, protection and promotion of human rights and rehabilitation of offenders. The LCS is envisioned as contributing to the maintenance and protection of a peaceful and safer society. However, over the years there have been speculations of human rights violations and lack of sufficient and basic infrastructural requirements.

\section{2. Politics of the Belly: Military Coups and Power in Post-Colonial Lesotho}

There is a consensus that there is ample evidence that shows that the expectations of millions of Africans has not been satisfied in the post-colonial era and this has brought with it failed expectations to many. Some African individuals fought against colonialism, hoping that the post-colonial dispensation would bring about much-needed freedom and material prosperity. However, some African leaders have formed states that besides failing to manage their economies and natural environment become the source of division and conflict among them. Africa's return to multiparty political dispensation in the late 1980s and early 1990s brought with it a renowned promise that political leaders would carry out needed democratic reforms, which had been hitherto suppressed during colonialism by single-party regimes.

Cheeseman and Fisher [31] believe that while colonialism brought with it its fair share of underdevelopment to some African societies, which is still witnessed today, post the colonial era, many African heads of states have also failed to steer much-needed development. Indeed, colonialism was responsible for what the authors call the elevation of "Big Man" politics and place individuals with the daunting task of governing vast territories with limited capacity, legitimacy or forms of democratic institutions. Thus, the promise of democracy has failed to up to expectations. It is in this vein that the collapse of democracy post-independence is somewhat viewed as a rational response to colonial constraints. 
From an Afrocentric perspective, and particularly over the last few decades, the security sector has arisen as a critical component in guaranteeing peace and security, especially in countries still witnessing political instability [32]. Several studies [12, 33] by various scholars on Lesotho all reflect a country that lies at a heart of robust political instability and a population that lives with uncertainties and insecurities mainly due to conflict. Lesotho has seen immense political infighting over the last five decades. In Southern Africa, it currently holds the record for the highest number of efforts at unconstitutional removal of heads of states.

It has witnessed both coups and attempted coups in 1970, 1986, 1991 and 1994 and another series of attempted coups in 1974, 1998, 2009, 2014 and these have over the years brought with them the assassination of those in power, including army commanders. To exemplify this, in an attempted military coup in 2014, the military took over police and government buildings around Maseru and also jammed radio stations and phones. Such instances clearly outline that apart from political instability, the military in Lesotho also contributes a significant role in the instability of the country. According to Kahuni [34], coups are caused because of a robust urge by the military to restore democracy in an authoritarian state and this is a good way of removing authoritarian leaders and replacing them with good ones. Again, in some instances, these coups are mediated by a collective desire for socio-economic and political participation. While the researcher tends to support Kuhuni's statement to some extent, this is not always the case. Some states that experience military coups have stable democracies, nevertheless, what drives these coups is that in most cases (regardless of which political party is in power or wins elections) the demands of some political and military elites are not taken into consideration nor met by the ruling party. This phenomenon is robustly witnessed in most African states, such as Somalia, South Sudan, Niger and so forth. Thus, Lesotho is no exception, the kingdom is a democratic state, however, many individuals in both politics and the military have a vast interest in the ruining of the state, hence, bringing with it immense political instability if some considerations are not met.

Literature traces such instability to the Kingdoms constitutional architecture, civil-military relations, electoral system and historical dynamics of state formation [35]. Indeed, the interactions among Lesotho's political leaders can be viewed as a game where the winner takes all and attempts to conquer the opponents either by fair or foul means. This also stems from the fact that Lesotho's political elites do not trust one another to refrain from abusing security agencies to gain political leverage. Hence, those in power often seek a declaration of support from the army with the notion that a vote of no confidence may be brought against them [36-39]. The researcher is of the view that those politicians who are closely aligned to the top brass of the military have tended to have more security protection in Lesotho. On the other hand, those who have had close ties to the military top brass but are not in power have in some instances brought disorder to the smooth stability of Lesotho.

Motsamai [36] asserts that the underlying instability in Lesotho may be because of its relatively short democratic history, driven by the engrained politicization of state and security administration, violent patterns, fractions and contestation over state power. This has also stemmed from contestation for power during and after elections, unsettled disputes of political impunity and military intervention in Lesotho's political process. It is in this essence that Lesotho's political disorder has always been rocked by poor governance or put simply, a political rivalry, which also led to the coalition government of 2014 (All Basotho Convention, LCD and Basotho National Party), resulting in an attempted coup [40].

Thus, the constitutionally overlapping mandate, given to security institutions, is arguably one of the reasons for the frequent military interference in the maintenance of law and order in Lesotho. It is in this vein that Letsie [41] is of the view that the LDF has a bad history in mixing itself in Lesotho's political affairs, encompassing but not limited to the overthrowing of a civilian government in 1986 and the assassination of a deputy Prime Minister in 1994. Similarly, fragmentation in political parties has often led to party splits and an unstable governance system. Equally, the entrenched alliance between political elites and certain branches of the security forces (army and police) have escalated hostilities between political elites, thereby destabilizing the governance system. Because of this, instability in Lesotho has been spearheaded by the militarization of poli- 
tics, upon which a culture of violence, malfeasance and impunity is anchored. Thus, such persistent violence in the tiny Kingdom has seen the country miss needed economic opportunities, loss of lives, a damaged continental image, political factions and poverty.

\section{3. The Role of Continental and International Actors in Lesotho's Political Pandemonium}

Many African (notably South Africa) states continental actors and other third parties have over the years offered their assistance in the Lesotho instability with the view of putting pressure on the Lesotho government to implement a wide range of governance reforms. These have included the SADC, the African Union (AU) the Commonwealth Secretariat and United Nations (UN), opposition parties and civil society among others. With regards to civil society, Philande [2] and Mlambo [42] are of the view that the involvement of civil society is of importance in the instance as in both established democracies and ones undergoing reforms, the involvement of civil society in policy processes is part of a democratic process as it ensures transparency and accountability.

For Pherudi [22], think tanks, such as the Institute of Security Studies (ISS), have hosted dialogues on civil-military relations, aimed at professionalizing Lesotho's security sector. Similarly, the Indian government under its Indian Army Training Team (IATT) also spent two years, training Lesotho's security sector, particularly the LDF. Other external actors have included Botswana, Britain, Zambia and Zimbabwe among others and these actors have over the years contributed troops and sent delegates to the negotiation table in an attempt to resolve Lesotho's instability. However, despite all these external interventions, Lesotho continues to be prone to continuous political and security crises, largely because of its security forces. From Monyake [35] assessment, democratic reform processes can be seen as an effort to provide the public good of stability, accountability and the rule of law, while further aiming to coordinate behavioural expectations among political elites, which results in reinstating peace to the benefit of the citizens.

However, Mlambo [42] maintains that these have been hard to implement in Lesotho irrespective of its small population and has always been a challenge for various actors to convince Lesotho to implement and abide by these reforms. The security sector is of importance to any democratic state and is driven by several elements, including but not limited to:

a. An increase of the security sector to comprise numerous government bodies (police, intelligence and judiciary rather than just the military)

b. A robust and clearly defined relationship between these security sectors

c. A detailed relationship between the security sector and various institutions of a democratic country, including parliament, judiciary, civil society and government and

d. A visibly defined relationship between national security aims and budget allocation to the security sector.

What is needed in Lesotho is an effective means of refining the country's security sector. Ideally, this would be a need for the overall formation of a democratically controlled security sector, possessing ample resources and an appropriate composition to fulfil the requirements of crisis prevention and uphold the rule of law. Such should not only be executed at the military level but other critical institutions that constitute the state security sector. This is drawn from the fact that in Lesotho, as often witnessed, the security sector, particularly the military, plays a critical role in determining the country's political movement. When instability starts, the security sector influences whether such a situation escalates or is brought to calm. Hence, these security reforms may include:

a. Community policy programmes

b. Administrative, tactical and human rights training

c. Existence of transparency and accountability in the security sector

d. Empowerment of the security sector to properly uphold the law and

e. The rule of law, independence and the impartiality of the justice system.

In essence, Moremoholo [43] contends that this security sector reform should entail the reform of critical state institutions of both the security forces and the justice system. A better-resourced and well-functioning security sector installs sufficient elements of the security arena that the Kingdom of Lesotho has failed to uphold since its independence. Nevertheless, the importance of civil society must also be brought in the democratization and consolidation of democracy. Over 
the years and particularly in democratic states, such as South Africa, civil society has been vital in stimulating law-making, policy-making and policy implementation to democratic government and holding them accountable.

Civil society has been a critical watchdog of government behaviour, also, given its relative proximity to the individuals who are voters of any sitting government, civil society possesses the requisite muscle to try and influence the competence of government and did play an effective role in Lesotho during the elections of 1993, 1998 and 2002. In recent years, the role of civil society has included voter and civic education, election monitoring, conflict management, management of intra-party conflict and electoral system reform among others. While some of the innovations of civil society have not been successful, they are currently involved in ongoing national dialogue processes to facilitate negotiations between conflicted parties.

Throughout the Kingdoms history of conflict, the SADC has facilitated interventions in collaboration with neighbouring states in search of peace and stability. However, a disturbing element is that there has never been a full restoration of peace. While the SADC has played a substantial role in the Lesotho conflict (particularly through the deployment of a contingent force, which has included military and intelligence military forces), it should continue to push for the inclusion of all relevant players in Lesotho, particularly the government, opposition parties, security forces, civil society and other relevant stakeholders in the dialogue process. In assessing the efficacy of both internal and external interactions, the vital focus should be on the extent, to which the different actor's mediations and facilitations have achieved the desired results. Regional and continental actors are aware that without political stability in any region, the prospect(s) of attaining regional economic development will be a challenge. Indeed, in evaluating continental actors desired results, the focus should be on the extent, to which these actors mediation and facilitation has achieved desired results. So far, and irrespective of the signing of the various Memorandums of Understanding (MOU) in Lesotho, most mediation agreements have been short term and always seem to occur again on or before elections.

\section{4. Theoretical Framework}

Because of being shaped by practical events and processes, theories materialize out of reality and assist in constructing a better understanding of the fluctuating dynamics of the global arena. A theory is meant to guide the researcher in conceptualizing a particular study, thus, with no theoretical setting, the study is deferred in an epistemological vacuity [10]. This article utilizes the conflict theory to better grasp the undertaking of what drives conflict. This is notwithstanding that numerous theories explain the nature of disagreements, frictions, discomfort, tensions, political, religion, age groups, the states and regional and international organizations. Such theories explain the origins of the conflict, their drivers and manifestations, their trajectories and their social, cultural and economic implications at the individual, group, country, regional and international level.

However, there neither is a monolithic theory of conflict nor is there any monolithic school of thought that explains the causes or effects of all conflicts in a given context [44]. The conflict theory, first proposed by Karl Marx, is a theory that explains that a society is in a state of continuous conflict because of the competition for limited resources, while also seeking to explain the general contours of conflict in society, how it starts and varies and the effects it brings. The theory holds that social order is maintained by domination and power rather than by consensus and conformity. The theory proposes that those with wealth and power try to hold on to it by all means possible. It views society as divided along the economic lines of economic class between the proletarian working class and the bourgeois ruling class.

According to Bartos and Wehr [45], since its inception, the theory has been used to explain a wide range of social phenomena, included but not limited to wars, revolutions, poverty, discrimination and domestic violence. It attributes most of the fundamental developments in human history, such as democracy and human rights, to capitalistic efforts to control the masses. Similarly, central to the theory are the issues of inequality, the division of resources and the conflicts that exist between different socio-economic classes. Conflict theorists generally view power as the fundamental feature of society, rather than thinking of society as held together by collective agree- 
ment, concerning a cohesive set of cultural standards where power is located and who uses it (and who does not) fundamental to the conflict theory. Again, inequalities of political power and social structure also drive conflict. Hence, the intensity of the conflict varies depending on the emotional involvement of the parties, the degree of solidarity within the opposing groups and the clarity and limited nature of the goals. This theory assists in the logical prognosis of the article as firstly, it informs the motive of what constitutes conflict in diverse ways. Secondly, it provides in part some understanding of why some states are more prone to conflict than others in a particular region.

\section{Discussion}

The power, possessed by both the military and police, has made them have a robust role in state affairs rather than institutions, mandated to safeguard Lesotho's citizens. The legitimacy of the security sector underpins restructuring, transparent and accessible security sectors enhance healthy civil-military relations. Scholars have argued that lasting transitions from military rule are hard to secure because the military retains the capacity to step back into the political landscape long after returning to the barracks [46]. Thus, the intervention of the military in politics could be linked to corporate interests and the fragmentation of party politics.

Indeed, in some instances, militaries are often used as political instruments by some victorious parties to suppress the opposition and at times, they sympathize with the losing party as they refuse to accept the election. The researcher concurs with the above viewpoint, as post-independence, most African states have been prone to electoral mayhem and the involvement of the state's security architecture in state politics. Thus, there should be a level of trust between the security sector and society, which now is not the case in Lesotho. Because of the proximity between the security sector and those in power, it is at times able to influence policy-making processes. Restructuring a state's security and political dynamic reforms is not an easy task, it requires a state managerial and dedication prowess and assistance from different role players and therefore an ample amount of time and effort is invested in the coordination of this process. Similarly, because of numerous actors (and particularly for Lesotho) encompassing varied interests, some are normally viewed as further escalating conflicts of interest.

In democratic states, democracy is considered consolidated when no noteworthy actors are trying to achieve their objectives through non-democratic alternatives and most citizens are of the view that democracy is the only feasible alternative and democratic institutions and procedures are universally accepted. In the same vein, when regular free and contested elections are a necessary condition for the consolidation of democracy in any democratic state globally [4]. However, as already alluded, in Lesotho this is not always the case as many individuals in state-driven institutions aim to achieve their objectives via non-democratic ways.

If Lesotho is to create conditions, in which it can escape from its current political conundrum that affects socio-economic development, justice and security dimensions must be tackled simultaneously both in the short and long run. Continuous instability can create resistance to external aid in developing countries, such as Lesotho, even though it is surrounded by hegemonic South Africa. Developing robust responsive, effective and accountable security and justice institutions is often a pivotal priority in countries, confronted with conflict. Both security and justice reforms can assist in supporting peacebuilding and reconstruction.

However, even when the conflict has been settled, it has a high risk (as witnessed in Lesotho) of repetition. There are often three basic components of good governance of the security and justice sectors (1) a set of capable and responsive institutions subject to a system of layered oversight (2) an array of governing principles and arms and (3) a comparative and effective framework [8]. In its 2017 sector reform document titled: The Lesotho, we Want: Dialogue and Reforms for National Transformation, the Government of Lesotho [8] stated that some objectives of its reforms are to stimulate national transformation in Lesotho. These would be done through (1) the promotion of long-term national stability, unity and reconciliation (2) the creation of professional functioning and effective institutions for the efficient management of public affairs, service delivery and development and (3) building a national consensus and implementation of constitutional changes as 
needed. However, while these have come to dominate national debate discussions over the years, little achievements have been attained concerning the country's security sector reforms.

In Lesotho, power and armed rivalry define the relationship between the ruling and opposition parties, which over the past few decades has deeply paralyzed Lesotho's internal political dynamics [12]. Although Lesotho's transition rule from colonialism to independence was seen as a positive development for the country's democracy, tense relations between the executive arm of the state and the security forces still linger. Lesotho's continued conflict has had severe repercussions for its economy and citizens and while both regional and continental actors have over the years tried to intervene, the conflict has continued to be witnessed in the Kingdom.

\section{Conclusion}

This article aimed to ponder on Lesotho's continued political instability and pay particular attention to the Kingdoms security services. One can safely declare that the Basotho nation has little to celebrate because the socio-economic challenges, which the country witnessed more than five decades ago, continue undiminished. The conflict has not yet settled in Lesotho as such instability is predominantly driven from the perimeters of those within the state (political actors and the security sector). The continuous politics of defections, doubtful state legitimacy, hatred and rivalry between those in power or wanting to seize power have over the years defined Lesotho's political existence. From the preceding, doubtful legitimacy is drawn from the association with detections and the always recurring events of wanting power by force.

The Kingdom currently finds itself at crossroads, in need of new avenues for strengthening the state and the effectiveness of its institutions, transforming its current political mayhem and managing its security sector will be indeed a difficult situation. Though some progress has been made in terms of the security sector reforms in Lesotho, however, more still has to be done. A critical element that will continue to shape security sector reforms in Lesotho will be how the parliament monitors and overseas both roles and functions of the security establishment. It is evident, that in Lesotho, democracy and good governance have been negatively impacted by the nature of its security sector. There is a need to build trust in Lesotho's security sector, encompassing an inclusive process, enforcing the security sectors reform processes. For a viable democratization process, political and other third parties should abide by the rules of electoral processes.

\section{References}

[1] Motsamai, D. (2018). Evaluating the Peacekeeping Effectiveness of SADC. University of the Witwatersrand, 259.

[2] Phungula, N. (2020). An assessment of the SADC Conflict Transformation Capacity in Lesotho 1998-2018: Towards a Conflict transformation Model. University of Kwazulu-Natal. Available at: https:/ukzn-dspace.ukzn.ac.za/handle/10413/18701

[3] de Wet, E. (2020). Military Assistance on Request and the Use of Force. Oxford: Oxford University Press. doi: http:// doi.org/10.1093/law/9780198784401.001.0001

[4] Malephane, L. (2015). Contesting and turning over Power: Implications for Consolidation of Democracy in Lesotho. Available at: https://afrobarometer.org/sites/default/files/publications/Policy\%20paper/ab_r6_policypaperno17.pdf Last accessed: 30.06.2021

[5] Hendricks., T., Musavengana, T. (2017). The Security Sector in Southern Africa. Pretoria. Pretoria: Institute of Security Studies.

[6] Brynard, D. J., Hanekom, S. X., Brynard, P. A. (2015). Introduction to Research. Hatfield: Van Schaik Publishers.

[7] Handbook on Police Accountability, oversight and Integrity (2011). United Nations. Available at: https://www.unodc.org/pdf/ criminal_justice/Handbook_on_police_Accountability_Oversight_and_Integrity.pdf Last accessed: 19.10.2021

[8] OECD (2007). The OECD DAC Handbook on Security System Reform (SSR): Supporting Security and Justice. Available at: https://issat.dcaf.ch/download/478/3015/OECD\%20DAC\%20Handbook\%20on\%20SSR.pdf Last accessed: 07.06 .2021

[9] Benyera, E. (2017). Towards an Explanation of the Recurrence of Military Coups in Lesotho. Available at: https://www.airuniversity.af.edu/Portals/10/ASPJ_French/journals_E/Volume-08_Issue-3/benyera_e.pdf Last accessed: 01.03.2021

[10] Shoemaker, P. J., Tankard, Jr., J. W., Lasorsa, D. L. (2004). How to Build Social Science Theories. London: Thousand Oaks. doi: http://doi.org/10.4135/9781412990110

[11] Williams, C. (2019). Lesotho in 2019: Looking Back to Find a Way Forward. Johannesburg: South African Institute of Internal Affairs. 
[12] Maundeni, Z. (2010). Political Culture as a Source of Political Instability. The Case of Lesotho. African Journal of Political Science and International Relations, 4 (4), 128-139.

[13] Sefa-Nyarko, C. (2020). Ethnicity in Electoral Politics in Ghana: Colonial Legacies and the Constitution as Determinants. Critical Sociology, 47 (2), 299-315. doi: http://doi.org/10.1177/0896920520943263

[14] Thomas, R. M. (2003). Blending Qualitative and Quantitative Research Methods in Theses and Dissertations. Thousand Oaks. doi: http://doi.org/10.4135/9781412983525

[15] Molomo, M. G. (1999). External Military Intervention in Lesotho's recent Political Crisis. External Military Intervention, 133-162. Available at: https://core.ac.uk/download/pdf/29179669.pdf Last accessed: 05.07.2021

[16] Motseki, M. M., Maluleke, W., Dlamini, S. (2020). Military role in democratic transition and succession: Lessons from the Kingdom of Lesothos. Cogent Social Sciences, 6 (1). doi: http://doi.org/10.1080/23311886.2020.1847845

[17] Government of the Kingdom of Lesotho (2017). The Lesotho we Want: Dialogue and Reforms for National Transformation. Vision, Overview and Roadmap. Available at: https:/www.gov.ls/wp-content/uploads/2019/07/Lesotho-Reforms-Frameworkand-Road-Map-Final-Draft-1-30-November-2017.pdf Last accessed: 30.07.2021

[18] Maps of the World (2021). Political Map of Lesotho. https://www.mapsofworld.com/lesotho/lesotho-political-map.html Last accessed: 16.10 .2021

[19] Pateman, R. (1992). Intelligence Agencies in Africa: a Preliminary Assessment. The Journal of Modern African Studies, 30 (4), 569-585. doi: http://doi.org/10.1017/s0022278x00011058

[20] Schreier, F.; Born, H., Caparini, M. (Eds.) (2013). The Need for Efficient and Legitimate Intelligence. Democratic Control of Intelligence Services: Containing Rogue Elephants. Hampshire: Ashgate Publishing.

[21] Caparini, M.; Born, H., Caparini, M. (Eds.) (2016). Controlling and Overseeing Intelligence Services in the Democratic States. Democratic Control of Intelligence Services: Containing Rogue Elephants. Hampshire. Ashgate Publishing.

[22] Pherudi, M. (2018). The Assassination of Military Commanders in Lesotho: Triggers and Reactions. Journal of Contemporary History, 43 (2), 117-133. doi: http://doi.org/10.18820/24150509/jch43.v2.7

[23] Ball, S. (2020). Secret History: Writing the Rise of Britain's Intelligence Services. Montreal: McGill - Queens University Press. doi: http://doi.org/10.2307/j.ctv10kmf7k

[24] Richelson, J. T. (2018). The US Intelligence Community. New York: Routledge.

[25] Hutton, L. (2009). Intelligence and Accountability in Africa. Available at: https://www.files.ethz.ch/isn/112461/JUL09INTELLIGENCEACCOUNT.pdf Last accessed: 22.10.2021

[26] Lijembe, M. (2015). Intelligence Services and Democratization in Africa. University of Nairobi, 126.

[27] Matlosa, K. (2020). Pondering the culture of violence in Lesotho: a case for demilitarisation. Journal of Contemporary African Studies, 38 (3), 381-398. doi: http://doi.org/10.1080/02589001.2020.1749246

[28] Rosenberg, S., Weisfelder, B. F. (2013). Historical Dictionary of Lesotho. Maryland: Scarecrow Press.

[29] Matlosa, K. (2005). From a destabilising factor to a de-politicised and professional force: The military in Lesotho. Evolutions \& Revolutions: A Contemporary History of Militaries in Southern Africa. Pretoria: Institute for Security Studies, 85-110.

[30] Ministry of Defence and National Security (2018). Government of Lesotho. Available at: https://www.gov.ls/ministry-of-defence-and-national-security/ Last accessed: 04.05.2021

[31] Cheeseman, N., Fisher, J. (2019). Authoritarian Africa: Repression, Resistance and the Power of Ideas. New York: Oxford University Press, 176.

[32] Motsamai, D. (2015). Elections in a time of instability: Challenges for Lesotho Beyond the 2015 Poll. Available at: https:// issafrica.org/research/southern-africa-report/elections-in-a-time-of-instability-challenges-for-lesotho-beyond-the-2015-poll Last accessed: 22.10 .2021

[33] Leshoele, M. (2021). The Political History of Military - Induced Conflict and Instability in Lesotho and its Economic and Development Implications. International Journal of African Renaissance Studies, 1-18. http://doi.org/10.1080/ 18186874.2021 .1962726

[34] Kahuni, P. (2017). The Security Sector Reform Debate in Post-Independent Africa South of the Sahara: A Critical Ethical Investigation Based on the Concept of Sovereignty and Anarchy. University of KwaZulu-Natal, 310.

[35] Monyake, M (2020). Assurance Dilemmas of the Endangered Institutional Reforms Process in Lesotho. Canadian Journal of African Studies. doi: http://doi.org/10.1080/00083968.2020.1834418

[36] Motsamai, D. (2014). The SADC emergency meeting on Lesotho has been concluded, but the big challenge is how the resolutions will be implemented in Maseru. Available at: https://issafrica.org/iss-today/challenges-ahead-for-sadcs-mediation-in-lesotho Last accessed: 29.10.2021

[37] Peace and Security Report: Kingdom of Lesotho (2019). Institute for Peace and Security Studies. Available at: https://media. africaportal.org/documents/peace_and_security_report_vol_1_2019.pdf Last accessed: 21.10.2021. 
[38] Neuendorf, K. A. (2002). The Content Analysis Handbook. The United States of America, Sage Publications.

[39] Philander, D. (2020). Security Reforms in Lesotho: Observation from a 3-day Dialogue Series. Available at: https://www.africaportal.org/publications/security-sector-reform-in-lesotho-observations-from-a-three-day-dialogue-series/ Last accessed: 06.08.2021

[40] Mlambo, D. N., Adetiba, T. C. (2020). Post-1994 South Africa's Peacekeeping and Military intervention in Southern Africa: Reference from the Democratic Republic of Congo (DRC) and Lesotho. Journal of Public Affairs, 20 (1), e1984. doi: http:// doi.org/10.1002/pa.1984

[41] Letsie, T. W. (2018). The case for demilitarising Lesotho. African Security Review, 27 (3-4), 291-307. doi: http://doi.org/ $10.1080 / 10246029.2019 .1614083$

[42] Mlambo, D. N. (2020). Reframing the Notion of Regional integration in Sub-Saharan Africa: What Role for Civil Society. Ebangi, 17 (3), 144-153.

[43] Moremoholo, E. (2005). The Role of the Military in the Political Conflict in Lesotho: With Special Reference to the 1998 failed coup d'etat. University of KwaZulu-Natal, 142.

[44] Lumumba-Kasongo, T. (2017). Contemporary theories of conflict and their social and political implications. Peace, Security and Post-Conflict Reconstruction in the Great Lakes Region of Africa. Oxford: African Book Collective, 29-48. doi: http:// doi.org/10.2307/j.ctvgc60jf.7

[45] Bartos, O. J., Wehr, P. (2002). Using Conflict Theory. New York: Cambridge University Press. doi: http://doi.org/10.1017/ cbo9780511613692

[46] Monyane, O. (2009). The Kingdom of Lesotho: An Assessment of Problems in Democratic Consolidation. Stellenbosch University. Available at: https://scholar.sun.ac.za/handle/10019.1/1136

Received date 12.10.2021

(C) The Author(s) 2021

Accepted date 23.11.2021

This is an open access article under the

Published date 30.11.2021

Creative Commons CC BY license

How to cite: Mlambo, D. N. (2021). A kingdom with many internal facets: power, politics and instability in a post-colonial state. Ramifications for public stability. EUREKA: Social and Humanities, 6, 79-90. doi: http://doi.org/10.21303/2504-5571.2021.002161 